\title{
Laboratory analysis of ammonium and nitrate concentration of Malalayang Beach Waters
}

\section{(Analisis laboratotium konsentrasi amonium dan nitrat Perairan Pantai Malalayang)}

\author{
LaurinaWaropen $^{1}$, Sipriana S. Tumembouw ${ }^{2}$ \\ ${ }^{1)}$ Undergraduate student at Aquaculture Study Program, Faculty of Fisheries and Marine \\ Sam Ratulangi University \\ 2) Lecturer at Aquaculture Study Program, Faculty of Fisheries and Marine Science Sam \\ Ratulangi University. Email: tsipriana@yahoo.com
}

\begin{abstract}
The purpose of the study was to measure the concentration of ammonium and nitrate of Malalayang Beach Waters. The water was sampling from three sampling stations that were considered to be representative for Malalayang Beach Waters. Methods of sampling techniques, descriptive field survey techniques and sampling locations, were performed at 3 places that were considered to represent the characteristics of Malalayang waters. The results of the Field Work Practice determined that this several sampling methods used sea water is one of Ammonium, point 1 by: $0.745 \mathrm{mg} / \mathrm{L}$, point 2 of: $0.752 \mathrm{mg}$ / L, point 3 of: $0,833 \mathrm{mg} / \mathrm{L}$, while nitrate 1 point for: $4.8 \mathrm{mg} / \mathrm{L}$, point 2 of: $2.7 \mathrm{mg} / \mathrm{L}$, point 3 at: $<0.5 \mathrm{mg} / \mathrm{L}$. The conclusion is that the water quality is good for a body of water that is in a situation where the existing parameters in these waters can be maintained and controlled well and remains stable at all times so as to achieve an optimal state as a habitat for fish and for aquaculture.
\end{abstract}

Keyword: Sea water, Parameters, Analysis, Ammonium, Nitrate

\section{INTRODUCTION}

Pollution is a condition that has changed from the original form to worse situation. The change in the original condition to a poor condition can occur as a result of input of contaminants or pollutants. According to Mahida (1993), the water becomes polluted due to the inclusion of too much waste whether from sewage, industry, domestic waste or human activities.
Water is a natural resource that is necessary for the livelihood of all people, and living organisms. Therefore, water resources must be protected in order to adequately sustain humans and all other living creatures.

Utilization of water for various purposes should be done wisely, taking into account the interests of present and future generations. Concerns over the environmental problems that humans can 
reduce the quality and comfort of life have begun to appear (Suparmoko, 1994).

It is clear that the sustainable use of natural resources needs to be one of the efforts in the protection of the ecosystem (Sastrawijaya, 2009). It is important therefore to have controls that are applied to ensure the careful use of resources in reducing the negative effects.

\section{RESEARCH METHOD}

Materials and tools to be used in field practice can be seen in Table 1 and Tabel 2 below.

Table 1. The Materials to be used in field practice and function

\begin{tabular}{|l|l|l|}
\hline No & Material & Function \\
\hline 1 & $\begin{array}{l}\text { Water } \\
\text { samples }\end{array}$ & to be analyzed \\
\hline 2 & Aqua & $\begin{array}{l}\text { to be used cleaning } \\
\text { solution }\end{array}$ \\
\hline 3 & Ice cubes & $\begin{array}{l}\text { for the preservation of } \\
\text { water samples }\end{array}$ \\
\hline 4 & Tissue & $\begin{array}{l}\text { used for drying } \\
\text { ingredients }\end{array}$ \\
\hline 5 & $\begin{array}{l}\text { Mask } \\
\text { used for respiratory } \\
\text { protection }\end{array}$ \\
\hline 6 & $\begin{array}{l}\text { Gloves } \\
\text { used for hygienic } \\
\text { purposes }\end{array}$ \\
\hline 7 & $\begin{array}{l}\text { Blue micro } \\
\text { spoon } \\
\text { solution } \\
\text { NO } 3 \text {-IK }\end{array}$ & $\begin{array}{l}\text { used to measure nitrate } \\
\text { spoon micro } \\
\text { solution } \\
\text { NH }\end{array}$
\end{tabular}

Table 2. The following instruments will be used in field practice and function.

\begin{tabular}{|l|l|l|}
\hline No & Tools & Function \\
\hline 1 & InScien Pro & $\begin{array}{l}\text { used for water test kits } \\
\text { to check the air quality }\end{array}$ \\
\hline 2 & A refrigerator & used for saving samples \\
\hline 3 & $\begin{array}{l}\text { Sample } \\
\text { Bottles }\end{array}$ & $\begin{array}{l}\text { used for containing } \\
\text { water samples }\end{array}$ \\
\hline 4 & Tubes & $\begin{array}{l}\text { used to fill the sample } \\
\text { bottles }\end{array}$ \\
\hline 5 & $\begin{array}{l}\text { Spectrophoto } \\
\text { meters }\end{array}$ & $\begin{array}{l}\text { used for analyzing } \\
\text { Ammonium and Nitrate }\end{array}$ \\
\hline 6 & $\begin{array}{l}\text { A camera } \\
\text { used to documentation } \\
\text { tool }\end{array}$ \\
\hline
\end{tabular}

\section{Ammonium Concentration Measurement}

1. Measurements are made using test tubes and spectrophotometer cell

2. Press the mode button to set the measurement

3. Insert the round tubes, with a barcode, into a cell for a round tube and align it right into the dash of the degree photometer

4. Take a $6 \mathrm{ml}$ sample test tube and insert it into the cell. Then add 1 scoop of blue microspoonA1-ik into the test tube with a test tube cap tightly in place and shake it until all the reagents are dissolved, then place it into the test cell.

5. After reading, the color of sample solution will remain stable for 15 minutes.

\section{The Measurement of Nitrate Concentration:}

1. Take a sample and put it into a test tube, then add 1 pint of Blue micro spoon NO3 into the test tube, close the screw cover, and 
insert it into the test cell. 2. After reading, the color of the sample solution will remain stable for 60 minutes.

\section{Sampling}

The method used in this field practice was the descriptive method with field surveys and sampling techniques. Water sampling was carried out around Malalayang city of Manado. The sampling site consists of three points, then each sampling point sampling 3 times repetition. 1 point was taken at the mouth of the Estuary times Malalayang, then point 2 was taken in front of the restaurant, and point 3 is taken in front of the Boboca monument. Water sampling was done at high tide in sunny conditions. Water samples were taken directly at the water locations that have been determined by using a water bottle that had been prepared. The samples were then put into the fridge. The analysis of water samples was carried out in the Environmental Laboratory of Water Quality, Aquaculture Studies Program, Faculty of Fisheries, SamRatulangi University.

\section{Data Analysis}

Water samples were analyzed in the laboratory.

\section{RESULT AND DISCUSSION}

Results of analysis of water samples presented in Tabel 3.

\begin{tabular}{|l|l|l|l|}
\hline No & $\begin{array}{l}\text { WATER } \\
\text { SAMPLE }\end{array}$ & \multicolumn{2}{l|}{ PARAMETERS } \\
\hline & & ANH $_{\mathbf{4}}$ & N0 $_{3}$ \\
\hline 1 & Point 1 & $10.745 \mathrm{mg} / \mathrm{L}$ & $4.8 \mathrm{mg} / \mathrm{L}$ \\
\hline 2 & Point 2 & $20.752 \mathrm{mg} / \mathrm{L}$ & $2.7 \mathrm{mg} / \mathrm{L}$ \\
\hline 3 & Point 3 & $30,833 \mathrm{mg} / \mathrm{L}$ & $<0.5 \mathrm{mg} / \mathrm{L}$ \\
\hline
\end{tabular}

\section{Ammonium}

The ammonium concentration values (mg /L) in coastal waters of Manado illustrates that domestic waste accumulated on the beach at Malalayang is relatively closed or semi-closed and resulted in the concentration of ammonium in estuarine waters of $0.745 \mathrm{mg} / \mathrm{L}$ (deviate from the quality standards for the waters and marine aquaculture).Ammonium levels that are good for the life of the fish should be lessthan1mg/L= ppm (Sylvester, 1978, Asmawi, 1986 in Uno, 1996). The value of the average concentration of $0.752 \mathrm{mg} / 1$ atthe mouth of the station on the rightwas0.752mg/1(deviate from the quality standards for aquaculture and aquatic biotamg/L (deviate from the quality standards for aquaculture waters and marine life), and the value of the average concentration of ammonium in the estuary at the front of the station was $0.745 \mathrm{mg} / 1$ (deviate from the quality standards for aquaculture waters and marine life). It was seen that it is necessary to control the quality of water so that the concentration remains lessthan $0.745 \mathrm{mg} / 1$, (corresponding water quality standards for aquaculture and marine). The ammonium concentration values on the left side of the estuary had a value that is the same as the concentrations at the other sites. It was seen that there were high levels of organic matter content in these waters, which can interfere with activities of aquaculture and marine life.

The Water Quality Standards applicable in Indonesia, according to the PP. RI. NO. 82.,dated December 14, 2001 (Whardana, W.1999, states that the maximum limit recommended of ammonia content in the water bodies to be used as drinking water for public purposes is a Class C water source with $0.01 \mathrm{mg} / \mathrm{L}$ ). 


\section{Nitrate}

Water nitrate levels affect fertility because it affects the lives of aquatic microorganisms. Healthy Nitrate levels for supporting life are $<0.5 \mathrm{mg} / \mathrm{L}$.

The water sample point 1measured $4.8 \mathrm{mg} /$, the water sample point 2 measured $2.7 \mathrm{mg} / \mathrm{L}$, and the water sample point 3 was $<0.5 \mathrm{mg} / \mathrm{L}$. Acceptable water quality standards in Indonesia according to the PP. RI. NO. 82 In 2001, dated December 14, 2001, allow a maximum recommended limit of nitrate content in the water body of 5mg/L, category C (Fisheries).

\section{CONCLUSION}

The results of field practice that has been done can be summed up as follows: 1.Ammonium and nitrate tests have been successfully carried out in the Laboratory of Water Quality Environmental Studies Cultivation Program, Faculty of Fisheries, University of SamRatulangi. The ammonium content in the water sample taken at point 1 was $0.745 \mathrm{mg} / 1$. At point2 it was $0.745 \mathrm{mg} / 1$ and atpoint3it was $0.833 \mathrm{mg} / 1$. The levels of nitrate in the water samplesatpoint1 were $4.8 \mathrm{mg} / 1$; point 2 was $2.7 \mathrm{mg} / 1$, and in water samples point 3 the levels were $<0.5 \mathrm{mg} / 1$. The water samples taken at point 1 and 2 showed some contamination of nitrates. 2.Ammonium and Nitrate levels turned out to be within the tolerance of the life aquatic organisms

3.At higher the temperatures, the solubility of oxygen in the water decreased. 4. The quality of water is good for a body of water that is situated where the existing parameters in these waters can be maintained and controlled well and remains stable at all times so as to achieve an optimal state for aquaculture and fish habitat.

\section{REFERENCES}

Darmono. 2000. Lingkungan Hidup dan Pencemaran. UI Press Jakarta.

Effendi H. 2003. Telah Kualitas Air; Bagi Pengelolaan Sumber Daya dan Lingkungan Perairan. Kanisius Anggota IKAPI. Yogyakarta

Mahida UM. 1993. Pencemaran Air dan Pemanfaatan Limbah Industri. Raja Grafindo Persada Jakarta.

Suparmoko. 1994. Ekonomi Sumbedaya Alam Dan Lingkungan (Suatu Pendekatan Teoritis) Edisi 2. BPFE Anggota IKAPI, Yoyakarta. 411 hal

Sastrawijaya TA. 2009. Pencemaran Lingkungan. Rineka Cipta. Jakarta. 317 hal

Uno T. 1996. Studi Parameter Fisika, Kimia, Biologi di Perairan Danau Tondano. Skripsi. Fakultas Perikanan dan Ilmu Kelautan Unsrat. Manado

Wardhana AW. 1999. Dampak Pencemaran Lingkungan. Penerbit Andi Yogyakarta. 284 hal. 